\title{
POR UM CONCEITO DE PRESUNÇÃO
}

FOR A CONCEPT OF PRESUMPTION

Florence Haret*

Resumo:

O presente trabalho teve por objeto circunscrever os planos do significado de presunção, buscando determinar, de forma precisa, o conceito que preenche o sentido do termo. Procurou-se pôr em evidência os limites da idéia que evoca a atividade de presumir, determinando as diferentes acepções da palavra nos mais variados domínios do conhecimento humano. Partindo-se da Filosofia, passou-se pela Teoria da linguagem e Teoria Geral do Direito, buscando instrumental suficiente para elucidar o conceito no Direito Tributário. Definido o sentido da palavra, foram ressaltadas as vedações impostas pelos princípios que regem o subdomínio tributário no uso dos recursos presuntivos.

Palavras-chave: Presunção. Direito. Filosofia. Princípios.

\begin{abstract}
:
This work discusses the meaning of presumption, seeking to establish a precise concept that denotes the meaning of the term, highlighting the limits of the idea that evokes the activity of presumption, and to set different meanings of the word in the many fields of human knowledge. Based on the philosophy, it moved by the theory of language and general theory of law, seeking instrumental sufficient to elucidate this concept in tax law. Defined the meaning of the word, the fences that are imposed by the principles governing the sub domain of tax law were highlighted to show the restrict uses of presumption's resources in cases of tax imposition.
\end{abstract}

Keywords: Presumption. Law. Philosophy. Principles.

1. A tarefa de definir: $\mathrm{O}$ que é a própria definição?

Definimos, a todo momento, palavras e expressões; recorremos a dicionários por diversas vezes no nosso dia-a-dia; e, no entanto, ao definir o que é definição permanecemos perplexos em ver a dificuldade que esta tarefa nos exige. Eis que ao propor, neste estudo, definir o étimo presunção, será necessário entender, antes, o que significa a própria atividade de definir, que de tão usual, muitas vezes passa despercebida, sem, contudo, perder a sua essencialidade em todo trabalho que se pretende rigoroso.

A ação de definir associa-se a outros verbos como o de circunscrever, determinar, precisar, ou mesmo o de pôr ou assinalar limites a determinada coisa. De uma forma ou de outra, tem-se que a definição é uma atitude em que se busca demarcar

Doutora em Direito Tributário pela Faculdade de Direito da Universidade de São Paulo. Endereço eletrônico: florenceharet@hotmail.com. 
um objeto mediante inúmeras técnicas cognitivistas, mas que guardam uma mesma característica: o fato de serem sempre feitas mediante a enunciação de propriedades e características, capaz de diferenciar uma determinada coisa de outra(s). Assim o dizendo, é somente com a linguagem que a definição se mostra presente. E é enunciando sobre que se define o objeto em análise.

Podemos explicar o significado de uma palavra fazendo referência ao seu histórico, empreendendo uma análise etimológica da palavra; ou simplesmente descrevendo o objeto, enunciando as características físicas, perceptíveis aos sentidos; ou também associando a palavra a outras que ora guardam um significado próximo ora razoavelmente aproximado àquela que se pretende definir. Eis aqui as três espécies, respectivamente, histórica, nominal e real, de definição, as duas últimas abaixo elucidadas por Irving Copi:
A D. nominal vem a ser a determinação ou fixação exacta do significado de uma palavra nova ou desconhecida (D. puramente nominal) ou de sentido menos claro e preciso, por meio de qualquer sinônimo, da sua explicação etimológica ou da descrição de objecto por ela significado. ${ }^{1}$
Geralmente, a própria D. nominal, a etimológica sobretudo, é usada como introdução ao significado real, que todo o vocábulo tende naturalmente a evocar. A D. (explicativa) equivale à noção distinta e mais ou menos completa de um objecto. $^{2}$

Para a lógica, definir é determinar com rigor a compreensão exata de um conceito com ofim de o situar em relação a outros conceitos, classificando-o e distinguindo$o$. Estamos aqui, na teoria das relações - uma vez que nada é observado sozinho, mas sempre em vista do outro - e na teoria das classes e dos conjuntos - pelo simples fato de se classificar (colocar em classes) para o fim de distinguir uma coisa de outra, observandose sempre o grupo a que pertence. Enquanto na primeira, o conceito surge pelo tão só aparecimento da relação, ela mesma atributiva de significado; nesta última, opta-se por tomar um caractere específico (diferença) como referência para, em seguida, estabelecer semelhanças e disparidades entre unidades de um domínio considerado. De uma ou outra forma, enunciar sobre algo já é defini-lo.

A definição observada em seu aspecto formal, isto é, enquanto algo pensado, não passa de um conceito complexo que exprime a natureza ou essência de um objeto. De fato, não há como falar em essência, sem nos referir a Husserl, filósofo que atirou a atenção à chamada intuição eidética ou intuição das essências. Em suas inúmeras obras, procurou distinguir o fenômeno (fato) do nômeno (essência), sem contudo deixar de relacioná-los.

\footnotetext{
Logos. Enciclopédia luso-Brasileira de Filosofia. Lisboa/São Paulo: Editorial Verbo. v. 1, p. 1.299.

2 Id. Ibid., p. 1.299-1.300.
} 
Para ele, no fenômeno, isto é, o evento individualmente considerado, sempre se capta a essência de algo. Aliás, não há como a consciência captar o individual sem recorrer ao universal, que se faz aparente no nômeno. A essência, nesta medida, é justamente $o$ modo típico do aparecer dos fenômenos, ou melhor, aquilo que anuncia para a consciência as marcas do universal presentes em cada recorrência individual.

Por oportuno, estamos diante de dois tipos de conhecimentos: o do fenômeno e o do nômeno. Uma vez que os fatos particulares não são o eidos mas tão só casos de essências eidéticas, conhecer o fenômeno é algo diferente de conhecer o próprio nômeno. Exemplificando: ao se definir determinada coisa, tal como uma mesa, verifica-se que esta, essa ou aquela mesas são justamente tidas por mesas porque são casos particulares (fenômeno) da idéia (universal) que temos de mesa. Em cada recorrência a casos particulares, captamos uma essência universal, presente em todos os objetos mesa. Vale a ressalva de que isso não quer dizer que o conhecimento das essências seja um conhecimento mediato, ou seja, aquele obtido através da abstração ou comparação de vários fatos. Em verdade, o conhecimento das essências é intuição e, para Husserl, é intuição eidética. Posto isto, definir um objeto pela sua essência é conhecê-lo mediante a intuição presente no intérprete, segunda a qual dá ferramentas aptas a localizar aquilo de universal existente em cada recorrência fenomenológica. Dentre os tipos de definição que tome o eidos como referência, aponta-se aqui para aquela chamada essencial, uma vez que ela:

refere apenas os elementos essenciais, quer físicos (essência fisica, p. ex., homem = ser vivo composto de corpo e alma), quer metafísicos (essência metafísica, p. ex., homem = animal racional). A D. essencial metafísica constitui o tipo perfeito da $\mathrm{D}$. Nela se realiza plenamente a dupla finalidade a que toda e qualquer D. é destinada: dar de um objecto uma noção tão clara e precisa que se saiba exatamente o que ele é e se distinga nitidamente do que ele não é. Isto nos garante precisamente a $\mathrm{D}$. essencial com a indicação do gênero próximo (o que há de comum) e da diferença específica (o que há de próprio, exclusivo). ${ }^{3}$

E continua o Autor:

Mas nem sempre é possível obter uma D. essencial. Em geral, temos de nos contentar com definições imperfeitas, com simples descrições, que se limitam a indicar uma ou mais propriedade consideradas suficientes para distinguir uma coisa de outra. Podem ser de várias espécies:

3 Logos. Enciclopédia luso-Brasileira de Filosofia. Lisboa/São Paulo: Editorial Verbo. v. 1, p. 1300. 
a) descritiva propriamente dita, se as propriedades referidas decorrem necessariamente da essência (proprium), sendo com ela convertíveis (homem = animal que fala);

b) descritiva acidental, resultante da enumeração de propriedades comuns ou acidentais que, embora separadamente, convenham a muitos outros objectos, colectivamente tomadas, só convém ao definido;

c) descritiva causal, que explica uma coisa, não pelo que é em si mesma, mas pelas suas causas extrínsecas (eficiente = é um Stradivarius; final = é um cronômetro; exemplar = é um Moisés);

d) descritiva genética (constitutiva), se indica não só a causa, mas, sobretudo, o modo como uma coisa é produzida (o bronze é uma liga de diversos metais). ${ }^{4}$

Eis que as definições imperfeitas são as mais comuns e levam consigo uma margem de erro justamente por tomar os sentidos dos homens como base operatória da definição. Não é de todo inoportuno mencionar a este respeito que as sensações que cada pessoa leva de um objeto são subjetivas, sendo difícil objetivar algo necessariamente originário "da alma” do ser interpretante. Toda definição, portanto, já nasce limitada e restritiva.

Por fim, sob um outro ponto de vista, como formulação verbal, a definição também pode ser tida por juízo analítico, levando-se em conta, aqui, que o sujeito é representado pelo conceito a definir e o predicado por aquela propriedade ou conjunto de propriedades que constituem a sua estrutura íntima.

Cravada as premissas do estudo ora proposto, levemos em conta que a presunção é um conceito gerador de muitas dúvidas entre autores, em diferentes subdomínios do conhecimento e, agora em enfoque, no direito, servindo-se para representar inúmeras categorias que nada guardam de correlação entre si. Por que não aproveitarmos o ensejo para estabelecer os limites que estão faltando?

\section{A presunção na Filosofia}

Durante a antiguidade e a idade média, prevaleceu a concepção metafísica da filosofia, que tomava de Platão a idéia de que a filosofia seria o uso do saber em proveito do homem. Aristóteles, por seu turno, entendeu-a como "ciência da verdade", no sentido de que nela estão todas as ciências teóricas, atribuindo-lhe a função de unificar as ciências ou de reunir seus resultados numa "visão de mundo". Seria o que chamam de segunda concepção da filosofia. Mas o que se ressalva, no momento, é que tanto como ciência

4 Logos. Enciclopédia luso-Brasileira de Filosofia. Lisboa/São Paulo: Editorial Verbo. v. 1, p. 1.300. 
do saber quanto como ciência da verdade, a filosofia é uma sobrelinguagem de todas as ciências, na medida em que reflete sobre o próprio pensamento do homem, buscando as razões das coisas e das idéias. Em vista disso, ao se empreender uma análise do vocábulo presunção, é na filosofia que tomaremos o ponto de partida deste difícil empreendimento conceptual.

Para a filosofia, presumir é emitir um juízo sobre algo considerando-o válido até que se prove o contrário. Provar, aqui, está no seu sentido argumentativo, remetendo-se à própria retórica do convencimento. Em nível sintático, será verbalizado em proposições, sendo, deste modo, uma proposição que fala sobre algo sem certezas. Neste primeiro passo, a presunção seria tida por algo antecipado e provisório: antecipado, uma vez que é emitido antes mesmo do consenso entre as partes comunicantes de seu sentido; provisório, pois sempre poderá ser modificado quando enfrentado por outra proposição mais forte em tom retórico. Em resumo, a primeira definição do que seja o ato de presumir, na filosofia, seria assim apresentada:

1. juízo antecipado e provisório, que se considera válido até prova em contrário. Por ejemplo, 'P. de culpa' é um juízo de culpabilidade que se mantém até que seja aducida una prova en contrário; têm significado análogo as expressões 'P. de verdade' ou 'P. favorável' ou 'P. contrária' a uma proposição qualquer. $^{5}$

Estamos diante de uma definição descriptiva, imperfeita, segundo a qual, não sendo possível emitir uma noção clara e precisa pela própria complexidade do termo, limita-se a trazer elementos - juízo, proposição, provisoriedade, antecipação e validade até prova em contrário - considerados suficientes para distinguir a presunção de outros tipos de juízos.

Vale dizer que existem diversos tipos de presunções, sendo possível afirmar também que umas tem maior adesão do que outras em razão do próprio sistemas de lugares-comuns existente em uma determinada cultura, historicamente localizada. Neste sentido, buscando complementar a definição acima e objetivando maior determinação do significado da palavra em análise, é que pela técnica da definição puramente nominal que iremos consolidar o termo presunção por meio de outras palavras que lhe são sinônimas ou que, no mínimo, nos remete a um conceito aproximado. Assim sendo é que, neste momento, propõe-se determinar o étimo presunção associando à idéia de metáfora.

Etimologicamente, o termo metáfora deriva da palavra grega metaphorá, que significa junção de dois elementos - meta ("sobre") e pherein ("transporte"). Trata-

\footnotetext{
5 ABBAGnANO, Nicola. Dicionário de Filosofia. Trad. Alfredo Bosi, Ver. Ivone Castilho Benedetti. São Paulo: Martins Fontes, 2007. p. 926.
} 
se de uma palavra tomada em outro sentido; consiste no transporte de significados. Para Aristóteles, "A metáfora consiste em dar a uma coisa um nome que pertence a outra coisa; essa transferência pode realizar-se do gênero para a espécie, da espécie para o gênero, de uma espécie para outra ou com base numa analogia". ${ }^{6}$ Cícero, por seu turno, considerava-a como uma forma particular de comparação, ao passo que Aristóteles ela é o tipo principal (...)"ᄁ O ponto em comum desses dois filósofos é que a metáfora é a própria capacidade de perceber semelhanças. Para eles, o verossímil depende, em última instância, da opinião comum, isto é, do público. Lançar mão de idéias consensuais para a coletividade e inseri-las na argumentação faz alcançar os efeitos de espelhamento e identificação desejados, acabando por sugerir uma ação.

Ora na presunção essas características se fazem da mesma forma presentes. Já vimos que, ao presumir, estamos emitindo um juízo sobre algo, sem que, contudo, se tenha certeza dele. Eis porque toda presunção é antecipada e provisória. Mas, em geral, a presunção nasce de algum consenso, de uma idéia da opinião comum. E de forma a simplificar o próprio discurso, quando a prova do verdadeiro se torna demasiadamente penosa e de difícil elaboração, é que se admite este efeito de espelhamento e identificação desejado, isto é, em outras palavras, admite-se um juízo pelo outro, identificando aquilo que a princípio seria dissociado. É por assim dizer que a presunção "é o produto da interação específica de significados heterogêneos mas comuns". "Vale a ressalva de que "a noção de interação (...) não se trata apenas de confrontar objetos diferentes para estabelecer se alguma característica de um pode ser atribuído ao outro, mas de fazer uso de todo o nosso sistema de lugares-comuns para filtrar ou dispor um outro sistema, gerando assim uma nova organização conceitual (...)" ${ }^{9}$ Emprestada esta definição de metáfora, atribuindo-a às presunções, é que se torna perfeitamente possível afirmar que ao presumir: (i) fazemos uso de todo o nosso sistema de lugares-comuns; de forma que (ii) construímos um novo sistema de significação; que tem por resultado (iii) uma nova organização conceitual.

Tomamos aqui a visão clássica da metáfora, aquela desenvolvida na Antiguidade, sendo, portanto, uma noção substitutiva que objetiva compreender e experienciar uma coisa em termos de outra, tomando-se em conta o sistema de lugares comuns de uma determinada cultura. Eis que, por meio da definição nominal tonase necessário complementar o conceito de presunção atribuindo a ela as seguintes características:

\footnotetext{
6 ABBAgnanO, Nicola. Dicionário de Filosofia. Trad. Alfredo Bosi, Ver. Ivone Castilho Benedetti. São Paulo: Martins Fontes, 2007. p. 776.

Id. Ibid., p. 776.

8 Id. Ibid., p. 777.

9 Id. Ibid.
} 
(i) produto da intenção específica de significados heterogêneos mas comuns;

(ii) que lhe é conferido pelo efeito de espelhamento e identificação entre uma coisa e outra, construído pelo discurso em função primordial retórica;

(iii) gerando assim uma nova organização conceitual.

Desta forma, é possível enumerar as seguintes características à presunção, atribuído pela filosofia clássica:

(i) noção substitutiva

(ii) originária de um juízo antecipado e provisório;

(iii) criado através de um efeito de espelhamento e identificação entre uma coisa e outra; e

(iv) produto de uma interação específica de significados heterogêneos;

(v) garantindo assim uma nova organização conceitual.

Nestes termos, verificamos que, apoiando-nos na filosofia para associar a presunção à metáfora, a idéia daquela exige que o intérprete vá além do mero conhecimento lingüístico, o que não implica que o resultado conceitual de presunção se torne falso ou transgressor.

\section{A presunção na Teoria da linguagem}

Da filosofia à teoria da linguagem, sobrevoamos os horizontes da lingüística, da semiótica, da teoria dos atos de fala, para pousarmos nas concepções da nova retórica. Apoiada na semântica estrutural de Greimas, a nova retórica redefiniu a noção de signo deslocando-o do domínio psicológico (imagem acústica, conteúdo mental) e sociológico (o tesouro social da língua inscrito na memória de cada indivíduo) para uma análise puramente lingüística. Em outras palavras, o nível estratégico da semântica estrutural se desloca da palavra para o sema, isto é, da palavra para os traços semânticos das unidades lexicais manifestadas (morfemas). Passa-se da lingüística do plano da descrição e da classificação para àquel'outro da explicação.

Chaïm Perelman foi o grande percursor da nova retórica, sendo ele, portanto, nossa fonte para definir a presunção na teoria da linguagem. Em seu Tratado de argumentação, já no capítulo I - acordo - inicia o estudo sobre as premissas da argumentação dizendo que: "do princípio ao fim, a análise da argumentação versa sobre 
o que é presumidamente admitido pelos ouvintes". ${ }^{10}$ Para ele, toda argumentação envolve um conceito de auditório universal, relativo ao real, e outro de auditório individual, relacionado ao preferível. No primeiro, incluem-se os fatos, as verdades e as presunções; no segundo, os valores, as hierarquias e os lugares do preferível. Em suas palavras, "na argumentação, tudo o que se presume versar sobre o real se caracteriza por uma pretensão de validade para o auditório universal". ${ }^{11}$ A presunção, nesta medida, assim como os fatos e as verdades, é uma espécie de acordo, com sistema de alcance que pode se apresentar mais restritivo (os fatos) ou mais geral (as verdades) tendo em vista a adesão do auditório (páthos). Para ele:

as presunções estão vinculadas, em cada caso particular, ao normal e ao verossímil. (...) A própria existência desse vínculo entre as presunções e o normal constitui uma presunção geral admitida por todos os auditórios. Presumese até prova em contrário, que o normal é o que ocorrerá, ou ocorreu, ou melhor, que o normal é uma base com a qual podemos contar em nossos raciocínios. Essa base corresponderá a uma representação definível em termos de distribuição estatística das freqüências? Não, sem dúvida. E esta é uma das razões que nos obriga a falar de presunções e não de probabilidade calculada. ${ }^{12}$

Parte constitutiva do real, a presunção goza do acordo universal, no entanto, caracteriza-se, diferenciando-se dos outros procedimentos, por estar sujeita a ser reforçada em termos argumentativos. Segundo o ponto de vista de Perelman, a presunção é um raciocínio que, tomando o normal e o verossímil, estabelece uma relação entre duas coisas diferentes. Para tanto, não leva em consideração os dados de fato, como o resultado de uma estatística de ocorrências no mundo fenomênico, mas, estabelecendo uma relação, deduz um acordo entre o discurso (logos) emitido pelo orador (ethos) com seu auditório (pathos). Estamos aqui no domínio da definição lógica, em que o presumir não é observado sozinho, mas sempre em vista do outro. Eis que "todas as presunções baseadas no normal implicam um acordo acerca desse grupo de referência". ${ }^{13}$

Resumidamente, a teoria da linguagem vai tomar a definição da filosofia clássica, entendendo por presunção toda noção substitutiva, originária de um juízo antecipado e provisório, criado através de um efeito de espelhamento e identificação entre

\footnotetext{
10 PERELMAN, Chaïm. Tratado da argumentação: a nova retórica. Trad. Maria Ermantina de Almeida Prado Galvão. 2. ed. São Paulo: Martins Fontes, 2005. p. 73.

11 Id. Ibid., p. 74.

12 Id. Ibid., p. 80.

13 PERELMAN, Chaïm. Tratado da argumentação: a nova retórica. Trad. Maria Ermantina de Almeida Prado Galvão. 2. ed. São Paulo: Martins Fontes, 2005. p. 81.
} 
uma coisa e outra, produto de uma interação especifica de significados heterogêneos, acrescentando, os seguintes elementos:

(i) é um conceito relativo ao real;

(ii) que se dá por uma espécie de acordo universal;

(iii) com sistema de alcance que pode se apresentar mais restritivo (os fatos) ou mais geral (as verdades);

(iv) uma vez que está sujeito a ser reforçada em termos argumentativos;

(v) tendo em vista a adesão do auditório (páthos).

\section{A presunção na Teoria Geral do Direito}

Estreitando a análise da figura da presunção, buscamos guarida agora à teoria geral do direito, para dela afirmar, confirmar ou infirmar os conceitos até então construídos. A propósito, a teoria geral do direito encontra-se no domínio da gnosiologia que nada mais é que a teoria geral do conhecimento. É a partir da gnosiologia que encontramos instrumental suficiente para habilitar, a quem pretende interpretar o texto jurídico, a tarefa de conceituar a presunção em planos epistemológicos, isto é, no domínio do conhecimento específico das Ciências do Direito. E é tomando a teoria de Pontes de Miranda que seguiremos a proposta deste estudo.

Ao tratar sobre a difícil empreitada de definir as presunções, o mestre alagoano logo no início do seu Tratado bem alerta: "A sua definição também pertence mais à ciência que a conjunto de regras jurídicas". ${ }^{14} \mathrm{E}$ foi no plano da epistemologia - das Ciências do Direito - a que, para o autor, existem três grandes tipos de presunção:

(i) Paesumptiones iuris et de iure ou presunção necessária/ legal ${ }^{15}$

(ii) Praesumptiones iuris tantum ou presunção voluntária/ relativa $^{16}$

(iii) Praesumptiones facti ou a presunção probabilis/ mista. ${ }^{17}$

E explica:

\footnotetext{
14 MIRANDA, Francisco Cavalcanti Pontes de. Tratado de direito privado: parte geral. 2. ed. Rio de Janeiro: Borsoi, 1954. t. 3, p. 446.

15 Quaedam est talis, cui datar etiamsi contra quis probaret.

16 Alia, cui statur, donec contra probatur.

17 Alia, cui non datar aliquo modo, nisi adminicula habent.
} 
Na presunção legal absoluta, tem-se A, que pode não ser, como se fôsse, ou A, que pode ser, como se não fôsse. Na presunção legal relativa, tem-se $\mathrm{A}$, que pode não ser, como se fôsse, ou A, que pode ser, como se não fôsse, admitindose prova em contrário. A presunção legal mista é a presunção legal relativa, se contra ela só se admite a prova contrária $a$, ou $a$ ou $b .^{18}$

Elucidando em outras palavras, a presunção legal orienta a formulação das normas de direito no sentido de permitir a construção de determinados fatos jurídicos, ou melhor, fazer julgamento sôbre fatos, que se demonstram de difícil prova e investigação. Logo, a presunção legal admite um fato por outro, como se fossem um só, ou o mesmo. Nesta medida, o fato presumido A pode não ser, mas será tido, para o universo do direito, como se fosse; assim como da mesma forma pode ser, no mundo real, mas será observado como se não fosse no domínio das normas jurídicas. Lembremos que o direito cria sua própria realidade. Não está restrito ao senso dos eventos reais, da causalidade física, mas ao senso jurídico, do vínculo implicacional. Assim dizendo, o direito pode tratar um fato tanto como se fosse quanto como se não fosse, estando nele as fórmulas que guiam, no mundo jurídico, a sua própria criação, alteração e extinção, dentro do que se chama autopoise do sistema jurídico.

Neste caso, Pontes de Miranda se preocupou em diferençar a presunção da ficção dizendo:

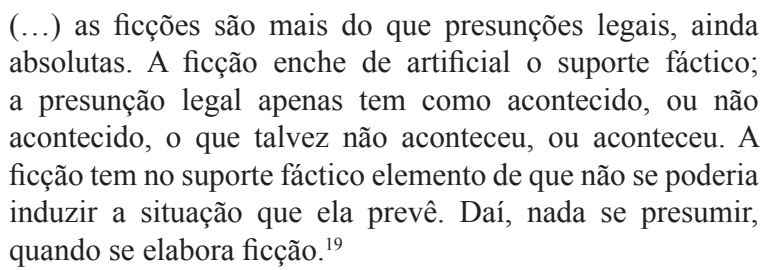

Tanto ficção quanto presunção no direito, deste modo, encontram-se como noção substitutiva, originária de um juízo antecipado e provisório, criado através de um efeito de espelhamento e identificação entre uma coisa e outra, produto de uma interação específica de significados heterogêneos. No entanto, enquanto a ficção é um juízo indutivo; a presunção é dedutivo. Nesta medida, a ficção é um conceito logicamente independente da experiência, por isso que tem no suporte fáctico elemento de que não se poderia induzir a situação que ela prevê. Já a presunção fixa suas bases no real, admitindo um fato por outro, como se fossem um só, ou o mesmo. Eis porque é um juízo dedutivo.

\footnotetext{
18 MIRANDA, Francisco Cavalcanti Pontes de. Tratado de direito privado: parte geral. 2. ed. Rio de Janeiro: Borsoi, 1954. t. 3, p. 446.

19 Id. Ibid., p. 447.
} 
Vale ressaltar que isto também já está em Perelman tendo em vista que, para este pensador, a presunção é sempre um conceito relativo ao real, com sistema de alcance que pode se apresentar mais restritivo (os fatos) ou mais geral (as verdades). Logo, presumindo-se, constrói-se um efeito de identificação com o mundo social que é subsumido à própria lógica do ordenamento do direito.

Já na presunção relativa, o elemento que a diferencia será a admissão de prova em contrário. Isto é, sendo a presunção um julgamento sôbre fatos que se demonstram de difícil prova e investigação, o argumento presumido é válido até que se encontre um meio de prova apto a desqualificá-lo. Da mesma forma, a presunção mista, que se diferencia da relativa apenas na forma, admitindo tão só determinadas e específicas provas contrária, em lei previamente estabelecidas.

A Teoria Geral do Direito, nesta medida, procurou dar à atividade de presumir uma definição segundo o papel que esta categoria de raciocínio tem no sistema do direito. De certa forma, por uma espécie de definição essencialista, enunciou elementos que deram ao objeto em análise uma noção clara e precisa para distingui-lo de outros - a ficção - que ele não é. Logo, a presunção é um julgamento sobre fatos, juízo dedutivo, que se faz presente em todo momento, no direito, que se mostra de difícil prova ou investigação. Assim o dizendo, verifica-se que o próprio sistema prescritivo de conduta estabelece, por meio de normas, a orientação que elucida o procedimento e o resultado dele para a constituição de determinado fato jurídico, necessário como ativação do vínculo implicacional e o posterior nascimento da relação jurídica.

Entendo, deste modo, que a presunção, no sentido pontiniano, guarda correspondência à definição clássica de metáfora acima traduzida. Independentemente de ser possível ou não produzir prova em contrário, é uma noção substitutiva criado através de um efeito de espelhamento e identificação entre uma coisa e outra, produto de uma interação específica de significados heterogêneos. Outrossim, ao atribuirmos a característica de provisoriedade - juízo antecipado e provisório - às presunções, observado o universo jurídico, contamos tão só com os tipos de presunção relativa e mista, uma vez que a presunção legal é constitutiva do fato, para o direito, sem que se admita prova em contrário. É a lei mesma que diz ser a presunção absoluta, também chamada de legal. Se nada disser a lei, entende-se a por relativa. A ausência de permissão de uma contraprova leva a presunção legal a um status de definitividade que não se encontra presente nos outros tipos presuntivos, alterando o próprio sentido que lhe foi atribuído da filosofia clássica, inclusive.

Em resumo, da teoria geral do direito, tiramos os seguintes elementos:

(i) a presunção é sempre dedutiva; 
(ii) tendo em vista que é um juízo dependente da experiência, isto é, fixa suas bases no real;

(iii) admitindo um fato por outro, como se fossem um só, ou o mesmo.

\section{A presunção no direito tributário}

Em comentário ligeiro, justamente para atender às estipulações que este estudo pretende, vale enumerar, em síntese, as características da presunção até agora encontradas:

(i) noção substitutiva;

(ii) originária de um juízo antecipado e provisório;

(iii) criado através de um efeito de espelhamento e identificação entre uma coisa e outra;

(iv) produto de uma interação específica de significados heterogêneos;

(v) garantindo, assim, uma nova organização conceitual.

(vi) é um conceito relativo ao real;

(vii) que se dá por uma espécie de acordo universal;

(viii) com sistema de alcance que pode se apresentar mais restritivo (os fatos) ou mais geral (as verdades);

(ix) uma vez que está sujeito a ser reforçado em termos argumentativos;

(x) tendo em vista a adesão do auditório (páthos).

(xi) É sempre dedutivo;

(xii) observado que é um juízo dependente da experiência, isto é, fixa suas bases no real;

(xiii) admitindo um fato por outro, como se fossem um só, ou o mesmo.

Levemos em conta essas injunções para aplicá-las ao subdomínio do direito tributário. Lembremos que, em linha de princípio, o direito é uno; porém, para fins epistemológicos, pode ser subdividido em diversos conjuntos, levando em conta a temática e as ilações específicas que regem o sentido e o procedimento de cada um desses agrupamentos. O direito tributário, por exemplo, é o conjunto de normas que dispõem sobre criação, arrecadação e imposição de tributos pelos entes tributantes. É um domínio que planta suas raízes na rígida discriminação competencial prevista na Carta Magna e, 
partindo dela, é que se enunciam regras e mais regras para o fim de regular a conduta do legislador ordinário no momento mesmo em que constrói as normas tributárias.

O direito tributário, desta forma, é um subdomínio do universo jurídico que exige tanto do poder legislativo - na elaboração das leis tributárias que criam, modificam e/ou extinguem tributos - quanto do poder executivo - quando da imposição e arrecadação dos tributos - rígido enquadramento do fato à norma, desde à limitação do poder tributante à norma de competência constitucional até o fato jurídico e o conseqüente da regra-matriz de incidência. Os princípios que regem a atividade destes entes tributantes exigem deles a estrita legalidade, isto é, que não existe imposição de tributo sem prévia lei que assim o estabeleça e a tipicidade fechada, que, em outras palavras, exige o exato enquadramento do fato à norma, subsumindo-se em todos os aspectos de forma precisa e mantendo sua correspondência.

Com base em interpretação sistêmica do direito tributário, é que já se pode afirmar que, neste específico campo do direito, a subsunção do conceito do fato ao da norma só se opera quando existente identidade absoluta entre um e outro, de forma que as hipóteses presuntivas, no que diz respeito à ocorrência do fato jurídico tributário, quando não previstas em lei, são vedadas. Em vista dos princípios da estrita legalidade e tipicidade já mencionado, cabe à administração provar os indícios do fato impositivo para, a partir deles, demonstrar a existência da relação de causalidade com o fato que se pretende dar por ocorrido.

Essa, inclusive, é a leitura que se deve tomar do princípio ontológico do direito que regula a ordem jurídica administrativa: "tudo que não estiver juridicamente permitido, estará proibido". Aplicando-o ao direito tributário, verifica-se que ele deverá ser observado com maior força uma vez que quando associado aos princípios axiológicos do subsistema constitucional tributário, especialmente o da estrita legalidade e o da tipicidade fechada, seria forçosa a ilação segunda a qual para qualquer imposição tributária, a previsão legal expressa é a forma constitucionalmente escolhida para legitimar qualquer cobrança a título de tributo. Eis que a figura da presunção no direito tributário deverá levar todas essas injunções em conta para o fim de deixar ingressar no direito tributário apenas os conceitos que respeitem estes limites.

Para iniciar o estudo da presunção neste subdomínio, tomemos as palavras de Alfredo Augusto Becker para quem as presunções são geradores de uma correlação lógica entre um fato conhecido e outro de provável acontecimento. Segundo o renomado jurista:

a observação do acontecer dos fatos segundo a ordem natural das coisas permite que se estabeleça uma correlação natural entre a existência do fato conhecido e a probabilidade de existência do fato desconhecido. A correlação natural entre a existência de dois fatos é substituída pela correlação lógica. 
Basta o conhecimento da existência de um daqueles fatos para deduzir-se a existência do outro fato cuja existência efetiva se desconhece, porém tem-se como provável em virtude daquela correlação natural. ${ }^{20}$

Desta forma, para se presumir, na dicção do mestre tributarista é necessário existir:

(i) fato conhecido;

(ii) fato desconhecido;

(iii) probabilidade de existência do fato desconhecido;

(iv) correlação natural entre a existência do fato conhecido e a probabilidade de existência do fato desconhecido;

(v) substituição desta correlação natural por uma correlação lógica.

$\mathrm{Na}$ dicção de Becker, tomando a correlação natural pela lógica é que se passa a ter, para o direito, um fato desconhecido por provável (natural) e deste fato provável a dedução (lógica) de sua existência. Logo, presumindo, o direito atribui ao fato desconhecido status de fato conhecido ou, no mínimo, existente. O processo intelectual da presunção exige, por assim dizer, estes dois raciocínios, associando-se o que, em tese, seria dissociado. Em outras palavras, para Alfredo Augusto Becker, a presunção é um raciocínio lógico que toma como ponto de partida uma correlação natural (razão pela qual é presunção e não ficção) para estabelecer com ela um vínculo lógico (por meio de uma dedução). E, neste sentido, é que ele traz a seguinte definição às presunções:

Presunção é o resultado do processo lógico mediante o qual do fato conhecido cuja existência é certa se infere o fato desconhecido cuja existência é provável. ${ }^{21}$

Relembra o autor, ao definir o instituto aqui estudado, que o ato de presumir é uma noção substitutiva, pois pede por uma substituição de uma correlação natural por uma lógica, que, de forma semelhante, mostra-se como algo constituído por um efeito de espelhamento e identificação entre uma coisa conhecida e outra desconhecida, portanto, produto de uma interação de significados heterogêneos. Do mesmo modo, é um juízo antecipado e provisório, na medida em que trabalha com probabilidades, conceito que necessariamente nos remete ao domínio de tempo presente, de enunciação do fato e futuro, de realização do fato, realização esta que é impreterivelmente incerta. Sendo assim, institui uma nova organização conceitual aplicada e admitida ao domínio jurídico. No

20 BECKER, Alfredo Augusto. Teoria geral do direito tributário. 4. ed. São Paulo: Noeses, 2007. p. 538.

21 Id. Ibid. 
mais, referindo-se a fato, é um juízo que fixa suas bases no real, obtendo, por meio de um processo dedutivo, um conceito dependente da experiência.

Posto isto, outro ponto relevante a ser tomado em consideração, neste momento, diz respeito às noções de processo e produto a que todo termo remete. Neste ponto, vale a ressalva que podemos sempre considerar tanto o procedimento utilizado para se chegar a um determinado resultado; quanto o próprio resultado. Assim sendo, é presunção tanto o processo lógico de presumir quanto o resultado dele. Paulo de Barros Carvalho, por exemplo, toma as presunções como um:

processo lógico em que de um fato conhecido infere-se fato desconhecido e, portanto, incerto. ${ }^{22}$ (Grifos meus)

Já José Eduardo Soares de Mello chama a atenção ao resultado deste processo, entendendo por presunção:

o resultado do processo lógico, mediante o qual do fato conhecido, cuja existência é certa, infere-se o fato desconhecido ou duvidoso, cuja existência é provável ${ }^{23}$ (Grifos meus)

Paulo Bonilha, por sua vez, colocando o enfoque também no resultado, na linha de Paulo de Barros Carvalho, diferencia-se em sua definição segundo o agente interpretante, no caso, a figura do julgador. Neste sentido, enuncia a presunção como:

o resultado do raciocínio do julgador, que se guia nos conhecimentos gerais universalmente aceitos e por aquilo que ordinariamente acontece para chegar ao conhecimento do fato provado. ${ }^{24}$ (Grifos meus)

Eis que é presunção tanto o processo lógico em que de um fato conhecido infere-se fato desconhecido e, portanto, incerto quanto o resultado dele, qual seja, a própria noção substitutiva, originária de um juizo antecipado e provisório, criado através de um efeito de espelhamento e identificação entre uma coisa e outra, produto de uma interação específica de significados heterogêneos.

Colocando em parênteses metodológicos os comentários supra, retomemos as palavras do ilustre prof. Paulo Bonilha, para tecer algumas outras considerações sobre o que foi levantado em sua definição. Segundo o autor, a presunção é percebida diferenciandose os conhecimentos gerais universalmente aceitos daquilo que ordinariamente acontece.

CARVAlHO, Paulo de Barros. Direito tributário, linguagem e método. São Paulo: Noeses, 2008. p. 842.

23 MELO, José Eduardo Soares de. Presunções no direito tributário. In: MARTINS, Ives Gandra da Silva (Coord.). Caderno de pesquisas tributárias. São Paulo: Resenha Tributária, 1991. v. 9. p. 336.

24 BONILHA, Paulo Celso B. Da prova no processo administrativo tributário. 2. ed. São Paulo: Dialética, 1997, p. 92. 
Neste ponto, ao remeter-se aos conhecimentos gerais universalmente aceitos, o autor de um lado retoma da filosofia clássica a idéia de que toda presunção nasce de algum consenso, de uma idéia da opinião comum; assim como também, da teoria da linguagem (nova retórica), a noção de acordo, com sistema de alcance que varia segundo a adesão do auditório (páthos). Tanto em um quanto em outro, o que se pretende dizer é que o senso comum, transformando-se em senso jurídico toda vez que permitido ou obrigado por lei, admite um fato pelo outro, constituindo o fato presumido. Esta, portanto, é uma noção substitutiva que se sustenta perante o auditório do direito na medida em que é universalmente aceito, isto é, tem adesão geral e, desta forma, torna-se uma verdade jurídica. Os conhecimentos gerais universalmente aceitos daquilo que ordinariamente acontece são, nestes termos, uma noção substitutiva, originária de um juízo antecipado e provisório, criado através de um efeito de espelhamento e identificação entre uma coisa e outra, produto de uma interação especifica de significados heterogêneos e que, por ser emitida por um juiz de direito, cumprindo o papel social de julgador, diferentemente daquel'outras emitidas pelo legislador, são provisórios, ou seja, admitem prova em contrária.

Com estes torneios, suponho demonstrado que, no direito tributário, as presunções, a despeito de guardarem correlação com a própria definição trazida da filosofia do direito e da teoria geral da linguagem, sofrem limitações do:

(i) princípio axiológico da estrita legalidade;

(ii) princípio axiológico da tipicidade fechada;

(iii) princípio ontológico do direito público em que "tudo que não estiver juridicamente permitido, estará proibido".

Eis que todo fato presumido em direito tributário deverá levar essas injunções em conta para o fim de deixar ingressar neste subdomínio do jurídico apenas os conceitos que respeitem estes limites.

Ponderadas essas colocações, parecer-nos perfeitamente justificada e coerente a adoção do seguinte conceito de presunção ao direito tributário:

(i) processo lógico que toma como ponto de partida uma correlação natural (motivo pelo qual é presunção e não ficção) para estabelecer com ela um vínculo lógico (por meio de uma dedução): O processo intelectual da presunção exige, por assim dizer, dois raciocínios - correlação natural entre o existente e o provável e correlação lógica entre o provável e o desconhecido - associando-se o que, em tese, seria dissociado.

(ii) resultado desse processo, qual seja, a própria atribuição atribui a um fato desconhecido de um status de fato conhecido ou, no mínimo, existente. 


\section{O conceito de presunção}

O presente trabalho teve por objeto circunscrever os planos do significado de presunção, buscando determinar, com precisão, o conceito que preenche o sentido do termo. Buscamos pôr, ou ao menos assinalar, os limites da idéia que evoca a atividade de presumir, determinando as diferentes acepções da palavra.

Breves investigações semânticas revelaram que presumir, em planos gerais, é uma noção substitutiva, criada através de um efeito de espelhamento e identificação entre uma coisa e outra, produto de uma interação específica de significados heterogêneos. É uma espécie de acordo, com sistema de alcance que pode se apresentar mais restritivo (os fatos) ou mais geral (as verdades), tendo em vista a adesão do auditório (páthos). É sempre dedutiva; e, portanto, logicamente dependente da experiência, pois fixa suas bases no real, admitindo um fato por outro, como se fossem um só, ou o mesmo.

No direito, teremos uma primeira diferença classificatória - admissão de prova em contrário - que determinará a própria característica de provisoridade e antecipação a que a filosofia clássica atribui a esta figura de pensamento. Sendo disposta em lei, a presunção é definitiva para o direito, sem apresentar, portanto, esta característica de provisório atribuída às presunções da filosofia clássica. Já os tipos presuntivos relativo e/ou misto, admitindo o direito prova em contrário, enquadra-se perfeitamente na noção filosófica, atribuindo-lhes os elementos de provisoridade e antecipação. Em assim entendendo, esses dois tipos de fato presumidos seriam o exato exemplo de um juízo sobre algo considerando-o válido até que se prove o contrário. Chamemos a atenção, contudo, que independentemente de qual espécie de presunção tratarmos todas elas serão verbalizadas em proposições, sendo, deste modo, uma proposição que fala sobre algo sem certezas.

Lembremos em planos sucintos que da definição geral de presunção, herdamos da Filosofia, os seguintes elementos:

1. noção substitutiva

2. originária de um juízo antecipado e provisório;

3. que produz um efeito de espelhamento e identificação entre uma coisa e outra; e

4. produto de uma interação específica de significados heterogêneos;

5. garantindo assim uma nova organização conceitual.

Já da Teoria da Linguagem, apresentada segundo as concepções da Nova Retórica, tomamos as características que seguem:

6. é um conceito relativo ao real; 
7. que se dá por uma espécie de acordo universal;

8. com sistema de alcance que pode se apresentar mais restritivo (os fatos) ou mais geral (as verdades);

9. uma vez que está sujeito a ser reforçada em termos argumentativos;

10. tendo em vista a adesão do auditório (páthos).

Por fim, da teoria geral do direito enumeramos as frases abaixos:

11. a presunção é sempre dedutiva;

12. (ii) tendo em vista que é um juízo dependente da experiência, isto é, fixa suas bases no real;

13. (iii) admitindo um fato por outro, como se fossem um só, ou o mesmo.

Pensamentos deslizam ao longo do eixo descritivo, impulsionados por uma eloqüência ordenada e vigorosa, bem na medida em que a ciência pede e recomenda, levando-nos a conceituar as presunções mediante associações, empreendendo uma verdadeira definição nominal do termo. Nesta linha é que se entendeu por oportuno relacionar as presunções às metáforas, uma vez que em o significado de base esta última é a própria capacidade de perceber semelhanças. Considerando que toda presunção admite um juízo por outro, identificando aquilo que a princípio seria dissociado ou, em planos mais concretos, tem como acontecido, ou não acontecido, o que talvez não aconteceu, ou aconteceu, ela se enquadra dentro da noção de percepção de semelhanças, figurando como uma verdadeira noção substitutiva própria do ato de presumir.

Transportando isso para o domínio do direito, em termos gerais, vê-se que presumindo, o ordenamento jurídico atribui ao fato desconhecido status de fato conhecido ou, no mínimo, existente. O processo intelectual da presunção exige, por assim dizer, estes dois raciocínios, associando-se o que, em tese, seria dissociado. O raciocínio lógico da presunção toma, portanto, como ponto de partida uma correlação natural (razão pela qual é presunção e não ficção) para estabelecer com ela um vínculo lógico (por meio de uma dedução).

Pudemos relevar, outrossim, que, no direito tributário, os raciocínios presuntivos sofrem uma série de restrições, por imposição mesma dos princípios que regem este específico subdomínio do direito. Para fins de imposição de tributos, a previsão legal expressa é a forma constitucionalmente escolhida para legitimar qualquer cobrança a título de tributo. Da mesma forma, quanto à tipicidade fechada, a subsunção do conceito do fato ao conceito da norma só se opera quando presente identidade absoluta entre um e outro, de forma que as hipóteses presuntivas, no que diz respeito à ocorrência do fato 
jurídico tributário, quando não previstas em lei, são vedadas. Eis que a figura da presunção no direito tributário deverá levar todas essas injunções em conta para o fim de deixar ingressar no direito tributário apenas os conceitos que respeitem estes limites.

Firmemos em conclusão que, para o direito tributário a presunção pode ser tanto o processo lógico em que de um fato conhecido infere-se fato desconhecido e, portanto, incerto quanto o resultado dele, qual seja, a própria noção substitutiva, criado através de um efeito de espelhamento e identificação entre uma coisa e outra, produto de uma interação específica de significados heterogêneos. Eis um breve esboço sobre o conceito de presunção.

São Paulo, junho de 2008.

\section{Referências}

ABBAGNANO, Nicola. Dicionário de filosofia. Trad. Alfredo Bosi, Ver. Ivone Castilho Benedetti.. São Paulo: Martins Fontes, 2007.

ARISTÓTELES. Arte retórica e arte poética. Trad. Antônio P. de Carvalho. Rio de Janeiro: Ediouro.

2005.

. Os três gêneros da Retórica. In: Retórica. Lisboa: Ed. Imprensa Nacional / Casa da Moeda, BECKER, Alfredo Augusto. Teoria geral do direito tributário. 4. ed. São Paulo: Noeses, 2007.

BONILHA, Paulo Celso B. Da prova no processo administrativo tributário. 2. ed. São Paulo: Dialética, 1997.

CARVALHO, Paulo de Barros. Direito tributário, linguagem e método. São Paulo: Noeses, 2008.

. A prova no procedimento administrativo tributário. Revista Dialética de Direito Tributário, São Paulo: Dialética, n. 34, 1998.

DINAMARCO, Cândido Rangel. Instituições de direito processual civil. 4. ed. São Paulo: Malheiros, 2004. v. 3.

LOGOS. Enciclopédia luso-brasileira de Filosofia. Lisboa/São Paulo: Editorial Verbo. v. 1.

MACHADO, Hugo de Brito. Local da ocorrência do fato gerador do ISS. Revista Dialética de Direito Tributário, n. 58, jul. 2000.

MELO, José Eduardo Soares de. Presunções no direito tributário. In: MARTINS, Ives Gandra da Silva (Coord.). Caderno de pesquisas tributárias. São Paulo: Resenha Tributária, 1991. v. 9. 
MIRANDA, Francisco Cavalcanti Pontes de. Tratado de direito privado: parte geral. 2. ed. Rio de Janeiro: Borsoi, 1954. t. 3.

PERELMAN, Chaïm. Tratado da argumentação: a nova retórica. Trad. Maria Ermantina de Almeida Prado Galvão. 2. ed. São Paulo: Martins Fontes, 2005. 